\title{
DESCRIPTION OF FAILURES AND RISKS THAT ARE EMERGED FROM LANDSLIDE MEASUREMENT ACTIVITIES IN INFRASTRUCTURE DEFORMATIONS
}

\author{
Eray Can, Hikmet Erbiyik
}

Original scientific paper

The occurrence of frequency of landslides that are considered parts of natural hazards continues to increase and their negative consequences affect human life, environment and urban infrastructures. In consideration of landslides that have remarkable destructive effects among the natural hazards, the importance of the engineering measurements and calculations in the geodetic network that is constructed in the landslide area plays an important role. A lot of factors affect the accuracy of the engineering measurements and calculations. Failure Mode Effect Analysis (FMEA) and Pareto Analysis methods are the effective tools in revealing these factors and alleviating their risks by taking relevant precautions. It may be possible to alleviate the risks to a minimum in the engineering measurements and calculations relevant to landslide parameters by these methods. We have attempted to alleviate failures and to take relevant precautions with FMEA and Pareto Analyses for the failures resulted in engineering measurements.

Keywords: FMEA analysis; infrastructure deformations; geodetic and topographic measurements; landslide monitoring; Pareto analysis

Opis promašaja i rizika nastalih zbog aktivnosti mjerenja odrona zemlje u deformacijama infrastrukture

Izvorni znanstveni članak

Učestalost pojave odrona zemlje koji se smatraju prirodnim opasnostima i dalje se povećava i njihove negativne posljedice utječu na ljudski život, okoliš i gradsku infrastrukturu. S obzirom na odrone zemlje koji među prirodnim nesrećama završavaju značajnim destruktivnim posljedicama, važnost tehničkih mjerenja i izračuna u geodetskoj mreži koja se izrađuje u područjima s odronima od velikog je značaja. Među velikim brojem čimbenika koji djeluju na točnost tehničkih mjerenja i proračuna, metode Failure Mode Effect Analize (FMEA) i Pareto Analize su učinkoviti alati u otkrivanju tih čimbenika i ublažavanju njihovih rizika poduzimanjem odgovarajućih mjera predostrožnosti. Tim je metodama moguće gotovo potpuno smanjiti rizike u tehničkim mjerenjima i proračunima relevantnim za parametre odrona. Pokušali smo ublažiti propuste nastale tehničkim mjerenjima i poduzeti odgovarajuće mjere predostrožnosti primjenom FMEA i Pareto analize.

\section{Ključne riječi: deformacije infrastrukture; FMEA analiza; geodetska i topografska mjerenja; nadziranje odrona zemlje; Pareto analiza}

\section{Introduction}

Human beings, in some cases are prone to a lot of natural hazards such as earthquake, flooding, landslide, tsunami, overflows, avalanches, etc. that are resulted from meteorological events that are realized in the atmosphere as well as in the active faults in the internal structure of the earth from the formation of the earth to the present time. While looking at the existing data relevant to natural hazards, we realize that there has been considerable increase in the amount of natural hazards, however, number of affected people and substantial losses have also

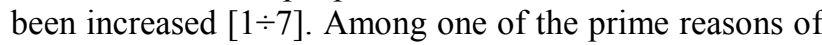
the increases in natural hazards is growth in population, expansion in industrialization, and the development of settlement and urbanization in the areas in which natural hazards occur frequently or there is the potential for natural hazards [8]

The landslides that make a substantial part among the natural hazards, may be defined as downward movement of rocks, debris and earth materials or mixture of those masses with effect of the attraction of gravity [9] (Fig. 1). The landslides may be propagated with geomorphologic, geologic, atmospheric and climatic effects and in addition to this fact may be triggered with various activities of human-beings [10]. The landslides that take an important part among natural hazards with regard to their devastating negative effects, cause substantial losses of human life and properties in the stricken areas as well as cause considerable destructions in the infrastructure of the urbans, in railways, highways and agricultural fields $[1,5,11,12]$. The studies of expert researchers and engineers in landslide issues play an important role in defining the incurred losses and potential losses in the landslide stricken areas, or in the landslide potential areas as well as avoiding the damages in advance of their occurrence. In order to define the area geometry and the borders by engineering geodetic measurement studies in the landslide area or in the potential landslide area, as well as monitoring the landslide indications and movements by sensitive GPS systems have significant importance.

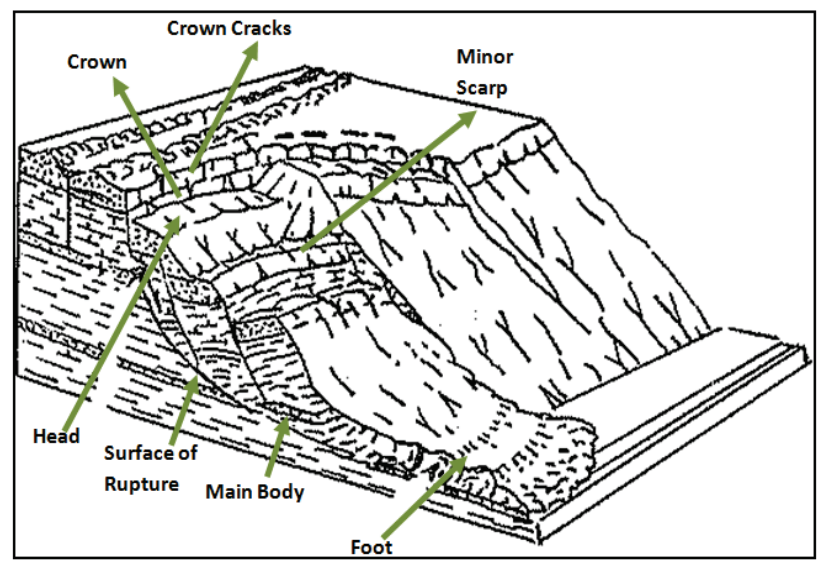

Figure 1 Natural landslide formation and its components [13]

However, after these monitoring studies the calculations of the vertical and horizontal axis parameters (curvature, unit deformation, etc.) of landslides by engineering calculations also becomes very important in description of landslide mechanism [11]. In addition, definition of geologic, geophysical, geomorphologic structure of the concerned settlement area also becomes 
very essential with regard to protection of the infrastructures in the area.

Specially in the dense settlement urban areas, landslide relevant risk analysis along side with these research studies play an important role in mitigating the landslide damages and providing life safety of the infrastructures and super structures in the concerned area. Among the major reasons for the landslide emergence in an area: geologic and tectonic features of the area, aggradations of the earth, physical and chemical features of the earth, distribution of rock and earth units in the area, topographic features of the field, beveled structure of the field, climatic and rainfall features of the area, etc. natural causes play an important role. In addition to this fact, humanitarian originated effects such as urbanization and engineering structures, agricultural activities, over ground and underground mining effects, irrigation, etc. in the area play important roles in landslide generation [8].

Fall down and breakage type landslides may be encountered frequently in the nature. In the case of soil or rock fall down incidents, the mass might do the free fall, bouncing, leaping or rolling movement in the air and mutual effects among the moving units during this type of fall down are rather very low [9]. On the other hand, gliding type landslide types are emerged due to reduction in the shearing strength along with the few gliding sections. Moreover, these sections have the detectability and predictability features as well [9]. Landslide types in the form of creeping emerge due to the moving or replacement of hillside spillages and loose materials over the wet or dry earth.

Basic reason of these movement types is the water, hence they are encountered frequently in the high rainfall areas. [9]. The landslides in the nature may be generated mostly in those three basic groups, however they also could be encountered in the combination form of those three groups due to the factors such as materials diversity that form the geologic and geomorphologic earth in the different periods of the landslide propagation process [9].

\section{The importance of topographic measurement studies in landslide analysis}

The share and place of topographic measurement activities is quite important in landslide analysis and other studies that are made towards landslides. In realization of landslide analysis, finding out topographic elevation values, calculations of hill side slope, calculation of horizontal and vertical axis curvature radius and finding the unit deformation amount in the area, the distances of the hillside crests are the important parameters that have to be included in definition of landslide geometry and carried out landslide risk analysis for urban infrastructures in the concerned area.

In the post review of the landslide potential areas or landslide stricken areas, it is also understood that the landslides are the kind of natural hazards that might occur also due to geologic, geophysical, geomorphologic and environmental features of the field as well as topographic features. Among those topographic features, specially field slope values, unit extension deformation and topographic hillside curvature (concave, convex, etc.) are the critical parameters that expert scientists studying in this field take primarily care of $[8,11]$. A well designed and well optimized geodetic network is first and foremost needed in the area in order to calculate and define those parameters in a sensitive manner in the landslide analysis in which those topographic parameters have important value. In a durable geodetic network that is to be carried out in the landslide area in that manner and equipped with the bent bars, the periodical observations made by the static measurement technique and by GPS technique will provide sensitive definition of those parameters. Furthermore, it might be appropriate to use sensitive leveling technique in the geodetic network that is to be constructed in the landslide zone in order to define the vertical axis topographic parameters in the geodetic measurement points. Specially, in the urban settlement areas that are constructed in the landslide potential zones, advance precautions might be taken against the probable damages and hazards on the infrastructure units such as highways, railways, sewerage lines, utility pipelines, electrical installation lines, etc. with the aid of those type observations. Conducting some control stages and risk analysis will be inevitable in advance and during the topographic measurements in order to make the geodetic topographic measurement and observations in a controlled manner and serve the intended objectives coherently. As we point out hereby one of the important analysis techniques that will make the basis of this study is Failure Mode Effect Analysis (FMEA) and following step implementation technique of the Pareto Analysis.

\section{Failure Mode Effect Analysis (FMEA) and Pareto analysis}

This risk analysis method provides the means for detecting the potential failures before their transformation into harms and eliminating and controlling the risks in an order starting from the major ones in the implemented systems and planning $[14 \div 16]$. Furthermore, apart from the other risk analysis methods, it will also provide the means for assessment of detectability of the risks in advance. On the other hand Failure Mode Effect Analysis (FMEA) as having a wide utilization area, is also a firm analysis technique in order to estimate the risks in advance and to prevent the potential harms before they occur $[16 \div 18]$. The implementation of this technique will be more appropriate during the design and development stage of the projects. The cost of the consumption resources will be lowest in the design and development stage compared to other system implementation stages. It is realized due to the corrective and preventive actions that are initiated after detected non-conformities during the overall system operation. The benefits of the system can be cited as follows:

- To develop the quality, reliability and safety of the formed system.

- To define priorities of the activities in the system.

- To reveal the potential failure modes and their similarities that will provide the means to assess their effects

- To enable the definition of potential critical and important characteristics.

- To enable a suitable platform for failure prevention. 
- To enable the definition of corrective and preventive actions.

- To monitor the risk mitigating activities.

Definition of a competent study team will be necessary in the FMEA studies as per the selected system because the definition of the potential problems and ascertaining of the Risk Priority Numbers (RPN) require knowledge and experience. During the design of the systems, the failures that the FMEA analysis comprises are handled in a certain system sequence and formula. However, there are 3 main elements in this analysis to define the priorities of the risks and failures. Those are defined as follows: Occurrence, Severity and Detection $[14,15,17,19,20]$. Among these elements, occurrence indicates the existence probability, defect frequency, (gradation system from 1 to 10 is used); severity or weight indicates the seriousness (effect) of the failuredefect, (gradation system from 1 to 10 is used), detectability means the level of difficulty in detecting the failure (gradation system of from 1 to 10 is used). However, the detectability element is also important due to its advantage of representing the failure's definition before happening. There are many alternative methods for defining the values of these elements.

Besides, the most customary way is to use numerical calculation tables (risk value tables). When the above mentioned three risk factor elements are assessed all together, it represents the risk priority level (RPL) for each failure-defect type. And this value defines the numerical level of critical risk [16, 19]. In calculation of risk priority level (RPL), the assigned values of risk factors are taken, that remain in a certain numerical range. Whilst the risks are defined for each failure type, starting from the biggest risk priority level (RPL), it is intended to reduce this risk level to an acceptable lowest level in a short term. On the other hand in the long term for eliminating these risks to initiate, the relevant and suitable corrective actions are intended. Risk priority levels (RPL) for FMEA is calculated by multiplying the Occurrence $(O)$, Severity $(A)$, and Detectability $(S)$ levels $[14,17$, $19 \div 22]$. In Tab. 1 Risk Priority Levels $(R P L)$ assessment table is given.

$$
R P L=O(\text { Occurrence }) * A(\text { Severity }) * S(\text { Detectability })
$$

Table 1 Risk priority levels $(R P L)[8]$

\begin{tabular}{|c|c|}
\hline Risk priority levels $(R P L)$ & Precaution \\
\hline$R P L<40$ & No need to take action \\
\hline $40 \leq R P L \leq 100$ & $\begin{array}{c}\text { Medium risk measures can be } \\
\text { taken }\end{array}$ \\
\hline$R P L>100$ & $\begin{array}{c}\text { Caution needs to be taken, high- } \\
\text { risk }\end{array}$ \\
\hline
\end{tabular}

Risk priority levels $(R P L)$ provide the definition of failures to be given priority in failure improvement studies by making priority rating. Risk priority levels $(R P L)$, while enabling the priority rating of failures, on the other hand provide a useful guidance to the relevant people who take part in the post assessment FMEA analysis, RPL values improvement studies.

On the other hand Pareto Analysis, is a kind of analysis method that facilitates the definition of risk priorities and it is used for estimating the percentage sequence and importance rate of any certain risks or problems among the other risks in the project [23]. Furthermore, it is also a kind of risk analysis that enables the formation of cumulative risk values with regard to the pre-defined risk threshold value (between $70 \%$ and $80 \%$ ) and hence it enables us to find out which type of risks are under the threshold value or above the threshold value and helps us to take relevant precautionary measures.

\section{$4 \quad$ Landslide monitoring and risk definition studies towards measurements of urban infrastructure deformations}

In the landslide incurred areas or landslide potential areas in urban settlements, the measurement processes for the landslides in ultimately accurate manner are very important as well as in order to make calculations of landslide topographic parameters in horizontal and vertical axis in precise manner. However, the above defined measures present importance as well in order to take precautionary measures in the infrastructures and superstructures of the urban settlements.

Definition and assessment of the failures and risks that might emerge from the topographic measurements and calculations in the landslide regions by systematic analysis methods such as FMEA Analysis and Pareto Analysis consist of the major part of the analysis. With the intended measurement processes and precautionary measures as a result of the risks and failures that are found here, horizontal parameters (horizontal gliding curvatures, horizontal gliding unit deformation) and vertical parameters (slope changes, vertical slope calculations, etc.) could be calculated in a more precise manner. If we come across the abnormal values in those calculated parameters, it will specially ease to take precautionary measures in urban settlement construction areas with landslide potential. In our study, as an implementation by utilizing the experiences and researches in scientific and vocational studies, due care is given to the three numbers of probable main risk and failure elements that the numbers of the risks could be increased in further studies, as shown in Tab. 1.

FMEA analysis, and main concentration is given to 11 numbers of the sub-parts of those risks In addition, in order to eliminate or mitigate those risks, vocational experiences are utilized and relevant solutions are attempted to offer. With the proposed solutions it is attempted to lower the Risk Priority Numbers $(R P N)$. The studied risk and failures as per the process sequence numbers are given below:

- The risks and failures arising from the realized measurements for the definition of landslide geometry and borders that are the part of landslide monitoring and measurement studies toward infrastructure protection in the landslide potential settlement areas (E10)

- The risks and failures arising from the measurement devices that are used in landslide monitoring and measurement studies toward infrastructure protection. (R10) 
Table 2 FMEA Table that is prepared for the landslide monitoring and risk definition activities towards infrastructure deformations in the urban settlements

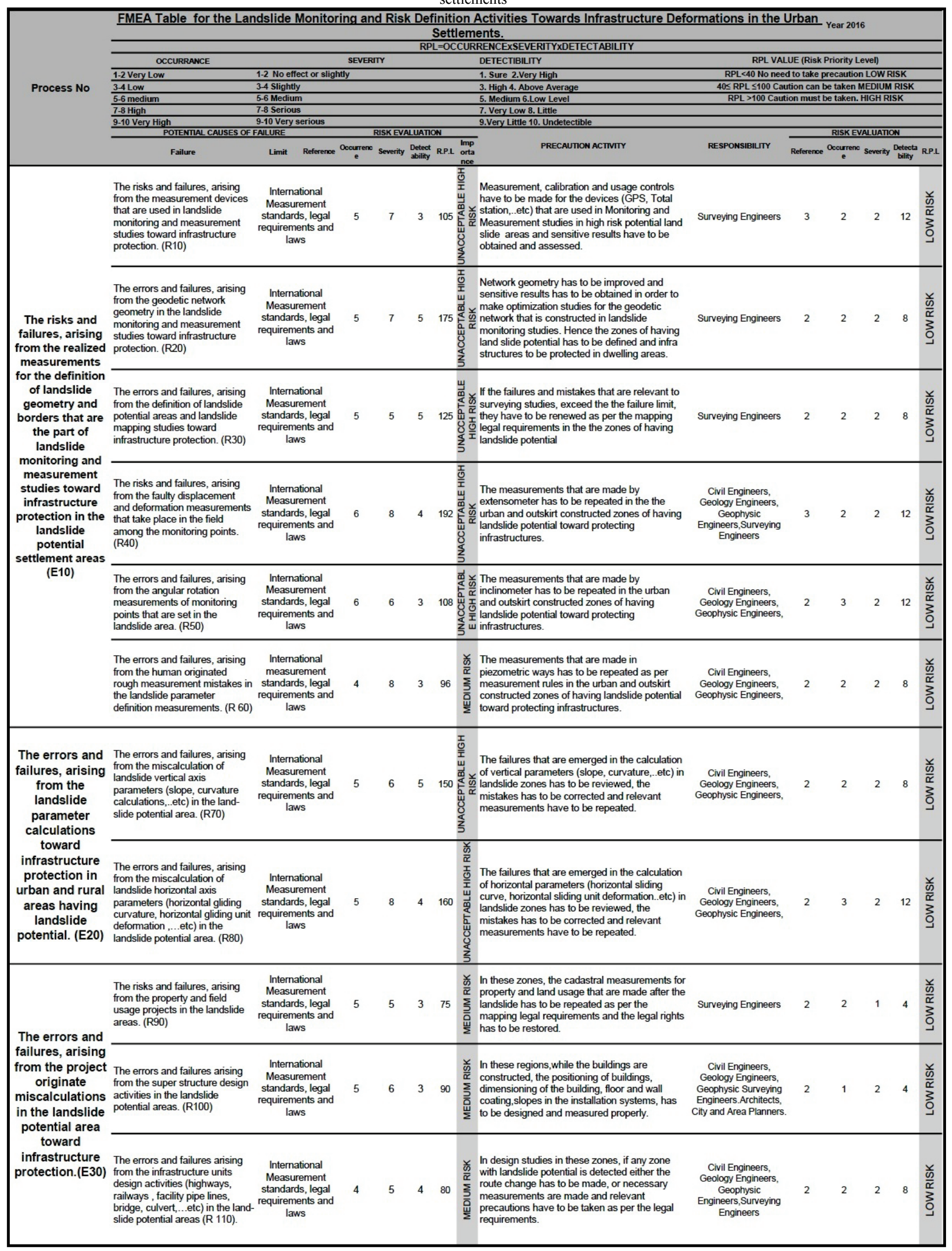


Table 3 Components of high risk error by $75 \%$ threshold value of the risks in the generated Pareto chart (high and medium risks)

\begin{tabular}{|c|c|c|c|c|c|c|}
\hline \multicolumn{7}{|c|}{$\begin{array}{l}\text { Components of High Risk Error by } 75 \% \text { Threshold Value of the Risks in the generated } \\
\text { Pareto Chart (High and Medium Risks) }\end{array}$} \\
\hline $\begin{array}{l}\text { SEQUENCE } \\
\text { NO }\end{array}$ & FAILURE MODE- & PROCESS NO & $\begin{array}{c}\text { RPL* }^{*} \\
\text { VALUE }\end{array}$ & RISK(\%) & CUMULATIVE RISK \% & $\begin{array}{l}\text { RISK } \\
\text { STATE }\end{array}$ \\
\hline 1 & $\begin{array}{l}\text { The risks and failures, arising } \\
\text { from the faulty displacement and } \\
\text { deformation measurements that } \\
\text { take place in the field among the } \\
\text { monitoring points. (R40) }\end{array}$ & 80 & 192 & 14.2 & 14.2 & 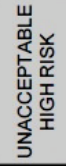 \\
\hline 2 & $\begin{array}{l}\text { The errors and failures, arising } \\
\text { from the geodetic network } \\
\text { geometry in the landslide } \\
\text { monitoring and measurement } \\
\text { studies toward infrastructure } \\
\text { protection. (R20) }\end{array}$ & 40 & 175 & 12.9 & 27.1 & 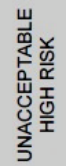 \\
\hline 3 & $\begin{array}{l}\text { The errors and failures, arising } \\
\text { from the miscalculation of } \\
\text { landslide horizontal axis } \\
\text { parameters (horizontal gliding } \\
\text { curvature, horizontal gliding unit } \\
\text { deformation, ...etc) in the } \\
\text { landslide potential area. (R80) }\end{array}$ & 20 & 160 & 11.80 & 38.9 & 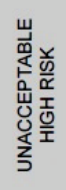 \\
\hline 4 & $\begin{array}{l}\text { The errors and failures, arising } \\
\text { from the miscalculation of } \\
\text { landslide vertical axis parameters } \\
\text { (slope, curvature } \\
\text { calculations,..etc) in the land- } \\
\text { slide potential area. (R70) }\end{array}$ & 30 & 150 & 11.1 & 50.0 & 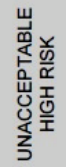 \\
\hline 5 & $\begin{array}{l}\text { The errors and failures, arising } \\
\text { from the definition of landslide } \\
\text { potential areas and landslide } \\
\text { mapping studies toward } \\
\text { infrastructure protection. (R30) }\end{array}$ & 70 & 125 & 9.2 & 59.2 & 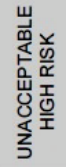 \\
\hline 6 & $\begin{array}{l}\text { The errors and failures, arising } \\
\text { from the angular rotation } \\
\text { measurements of monitoring } \\
\text { points that are set in the landslide } \\
\text { area. (R50) }\end{array}$ & 50 & 108 & 8.0 & 67.1 & 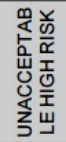 \\
\hline 7 & $\begin{array}{l}\text { The risks and failures, arising } \\
\text { from the measurement devices } \\
\text { that are used in landslide } \\
\text { monitoring and measurement } \\
\text { studies toward infrastructure } \\
\text { protection. (R10) }\end{array}$ & 10 & 105 & 7.7 & 74.9 & 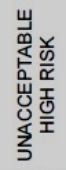 \\
\hline 8 & $\begin{array}{l}\text { The errors and failures, arising } \\
\text { from the human originated rough } \\
\text { measurement mistakes in the } \\
\text { land-slide parameter definition } \\
\text { measurements. (R 60) }\end{array}$ & 60 & 96 & 7.1 & 82.0 & 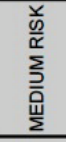 \\
\hline 9 & $\begin{array}{l}\text { The errors and failures arising } \\
\text { from the super structure design } \\
\text { activities in the landslide potential } \\
\text { areas. (R100) }\end{array}$ & 100 & 90 & 6.6 & 88.6 & 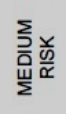 \\
\hline 10 & $\begin{array}{l}\text { The errors and failures arising } \\
\text { from the infrastructure units } \\
\text { design activities (highways, } \\
\text { railways, facility pipe lines, } \\
\text { bridge, culvert, .. etc) in the } \\
\text { landslide potential areas (R 110). }\end{array}$ & 110 & 80 & 5.9 & 94.5 & 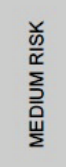 \\
\hline 11 & $\begin{array}{l}\text { The risks and failures, arising } \\
\text { from the property and field usage } \\
\text { projects in the landslide areas. } \\
\text { (R90) }\end{array}$ & 90 & 75 & 5.5 & 100.0 & $\sum_{\frac{1}{\Sigma}}^{\frac{w}{\alpha}}$ \\
\hline
\end{tabular}

- The errors and failures, arising from the geodetic network geometry in the landslide monitoring and measurement studies toward infrastructure protection. (R20)

- The errors and failures, arising from the definition of landslide potential areas and landslide mapping studies toward infrastructure protection. (R30)

- The risks and failures, arising from the faulty displacement and deformation measurements that take place in the field among the monitoring points. (R40)
- The errors and failures, arising from the angular rotation measurements of monitoring points that are set in the landslide area. (R50)

- The errors and failures, arising from the human originated rough measurement mistakes in the landslide parameter definition measurements. (R 60)

- The errors and failures, arising from the landslide parameter calculations toward infrastructure protection in urban and rural areas having landslide potential. (E20) 
- The errors and failures, arising from the miscalculation of landslide vertical axis parameters (slope, curvature calculations, etc.) in the landslide potential area. (R70)

- The errors and failures, arising from the miscalculation of landslide horizontal axis parameters (horizontal gliding curvature, horizontal gliding unit deformation, etc.) in the landslide potential area. (R80)

- The errors and failures, arising from the project originated miscalculations in the landslide potential area toward infrastructure protection. (E30)

- The risks and failures, arising from the property and field usage projects in the landslide areas. (R90)

- The errors and failures arising from the super structure design activities in the landslide potential areas. (R100)
- The errors and failures arising from the infrastructure units design activities (highways, railways, facility pipe lines, bridge, culvert, etc.) in the landslide potential areas (R 110).

Those indicated failures and risks have been listed as per the risk priority numbers (RPN) and risk importance ratings in Tab. 2 of Pareto analysis. In this study, while conducting Pareto Analysis, critical threshold value is accepted as $75 \%$, as the result of this analysis relevant graphic is depicted in Fig. 2.

Following the Pareto Analysis, the high risks are reassessed among themselves again with Pareto Analysis of $75 \%$ critical threshold value, the results are given in Tab. 3. The graphic that is obtained as the result of this analysis is depicted in Fig. 3.

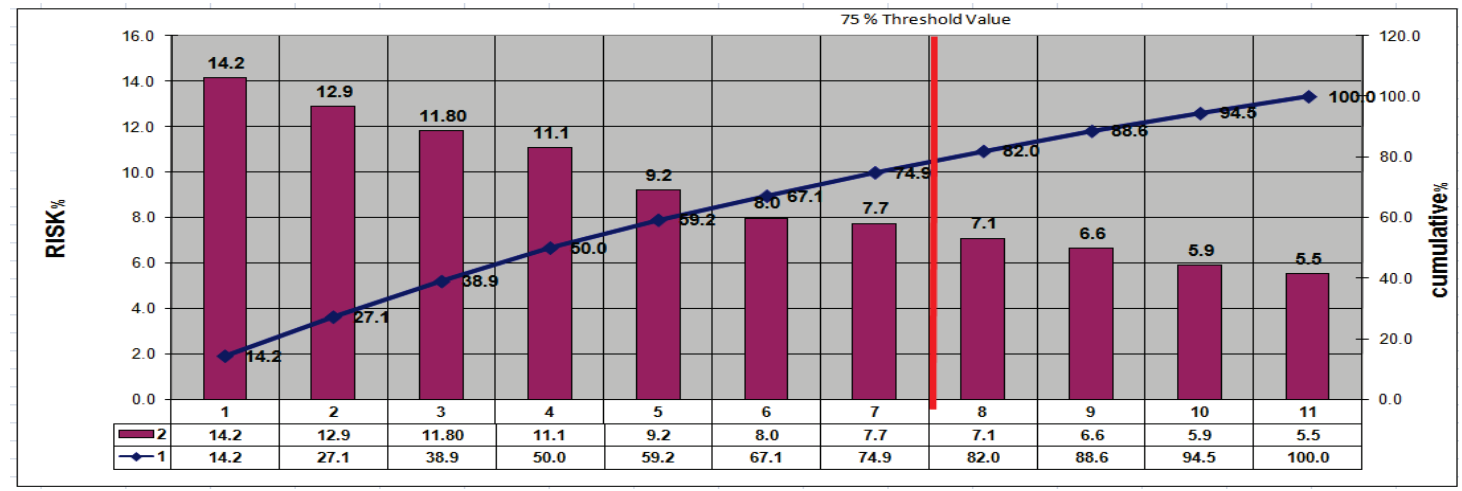

Figure 2 Pareto diagram resulting after Pareto analysis data evaluation (high and medium risks)

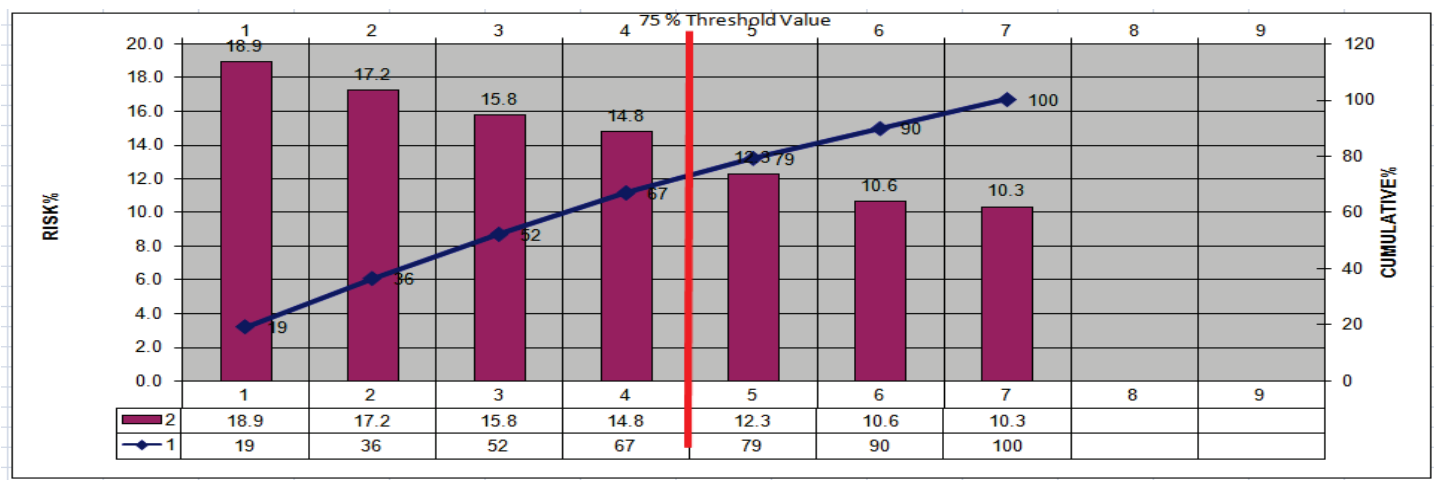

Figure 3 Pareto diagram resulting after Pareto analysis data evaluation for high risks

\section{Conclusion}

The landslides are among the natural disasters that play negative detrimental role in the society life with regard to life and property safety. Specially, in the urban areas where vital activities are sustained, the dimensions of these negative effects increase considerably.

Furthermore, these adverse incidents cause devastating effects in the infrastructure and superstructure of the urban areas as well as impose negative impacts on the economy of human society. For that reason, engineering measurements, calculations and design services become very important in order to take early precautions in the landslide potential areas.

Potential failures and risks that might emerge during the measurements, calculations and design services that are made in the landslide areas, are defined and analyzed with systematic FMEA and Pareto Analysis methods. Since these works will serve for mitigating the harms in the landslide stricken area, they are regarded very useful and important. In this study, it is shown that systematic FMEA and Pareto Analysis methods may be implemented successfully with the integration of engineering measurement and calculation services on the landslide cases that take part among the major natural disasters. As the result of the studies, and with utilizing the relevant vocational and expert knowledge, the relevant important conclusions are obtained and shown in Tabs. 2, 3 and 4. According to these results the following findings are set forward:

- The risks and failures, arising from the faulty displacement and deformation measurements that take place in the field among the monitoring points. (R40) 
- The errors and failures, arising from the geodetic network geometry in the landslide monitoring and measurement studies toward infrastructure protection. (R20)

- The errors and failures, arising from the miscalculation of landslide horizontal axis parameters (horizontal gliding curvature, horizontal gliding unit deformation, etc.) in the landslide potential area. (R80)

- The errors and failures, arising from the miscalculation of landslide vertical axis parameters (slope, curvature calculations, etc.) in the landslide potential area. (R70)

Table 4 Components of high risk error by $75 \%$ threshold value of the risks in the generated Pareto chart (high risk elements in their own error)

\begin{tabular}{|c|c|c|c|c|c|c|}
\hline \multicolumn{7}{|c|}{$\begin{array}{c}\text { Components of High Risk Error by } 75 \% \text { Threshold Value of the Risks in the generated Pareto } \\
\text { Chart (High Risk Elements in Their Own Error) }\end{array}$} \\
\hline $\begin{array}{l}\text { SEQUEN } \\
\text { CENO }\end{array}$ & FAILURE MODE- & PROCESS NO & $\begin{array}{l}\text { RPL" } \\
\text { VALUE }\end{array}$ & RISK(\%) & CUMULATIVE RISK \% & $\begin{array}{l}\text { RISK } \\
\text { STATE }\end{array}$ \\
\hline 1 & $\begin{array}{l}\text { The risks and failures, arising } \\
\text { from the faulty displacement and } \\
\text { deformation measurements that } \\
\text { take place in the field among the } \\
\text { monitoring points. (R40) }\end{array}$ & 80 & 192 & 18.9 & 19 & 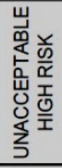 \\
\hline 2 & $\begin{array}{l}\text { The errors and failures, arising } \\
\text { from the geodetic network } \\
\text { geometry in the landslide } \\
\text { monitoring and measurement } \\
\text { studies toward infrastructure } \\
\text { protection. (R20) }\end{array}$ & 40 & 175 & 17.2 & 36 & 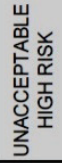 \\
\hline 3 & $\begin{array}{l}\text { The errors and failures, arising } \\
\text { from the miscalculation of } \\
\text { landslide horizontal axis } \\
\text { parameters (horizontal gliding } \\
\text { curvature, horizontal gliding unit } \\
\text { deformation,...etc) in the } \\
\text { landslide potential area. (R80) }\end{array}$ & 20 & 160 & 15.8 & 52 & 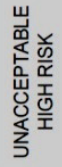 \\
\hline 4 & $\begin{array}{l}\text { The errors and failures, arising } \\
\text { from the miscalculation of } \\
\text { landslide vertical axis parameters } \\
\text { (slope, curvature } \\
\text { calculations,..etc) in the landslide } \\
\text { potential area. (R70) }\end{array}$ & 30 & 150 & 14.8 & 67 & 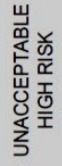 \\
\hline 5 & $\begin{array}{l}\text { The errors and failures, arising } \\
\text { from the definition of landslide } \\
\text { potential areas and landslide } \\
\text { mapping studies toward } \\
\text { infrastructure protection. (R30) }\end{array}$ & 70 & 125 & 12.3 & 79 & 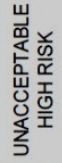 \\
\hline 6 & $\begin{array}{l}\text { The errors and failures, arising } \\
\text { from the angular rotation } \\
\text { measurements of monitoring } \\
\text { points that are set in the landslide } \\
\text { area. (R50) }\end{array}$ & 50 & 108 & 10.6 & 90 & 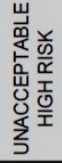 \\
\hline 7 & $\begin{array}{l}\text { The risks and failures, arising } \\
\text { from the measurement devices } \\
\text { that are used in landslide } \\
\text { monitoring and measurement } \\
\text { studies toward infrastructure } \\
\text { protection. (R10) }\end{array}$ & 10 & 105 & 10.3 & 100 & 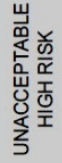 \\
\hline
\end{tabular}

\section{References}

[1] Düzgün, H. S. B.; Özdemir, A. Landslide Risk Assessment and Management by Decision Analytical Procedure for Derekoy, Konya, Turkey. // Natural Hazards. 39, 2(2006), pp. 245-263. DOI: 10.1007/s11069-006-0026-6

[2] Gorsevski, P. V.; Brown, M. K.; Panter, K.; Onasch C. M.; Simic, A.; Snyder, J. Landslide detection and susceptibility mapping using Lidar and an artificial neural network approach: a case study in the Cuyahoga Valley National Park, Ohio. // Landslides. 13, (2016), pp. 467-484. DOI: 10.1007/s10346-015-0587-0

[3] Lee, S.; Won, J. S.; Jeon, S. W.; Park, I.; Lee, M. J. Spatial Landslide Hazard Prediction Using Rainfall Probability and a Logistic Regression Model. // Math Geosci. 47, (2015), pp. 565-589. DOI: 10.1007/s11004-014-9560-z

[4] Zhang, Z.; Yang, F.; Chen, H.; Wu, Y.; Li, T.; Li, W.; Wang, Q.; Liu, P. GIS-based landslide susceptibility analysis using frequency ratio and evidential belief function models. // Environ Earth Sci. 75, (2016), p. 948. DOI: 10.1007/s12665-016-5732-0

[5] Yalçınkaya, M.; Bayrak, T. Comparison of Static, Kinematic and Dynamic Geodetic Deformation Models for Kutlugun Landslide in Northeastern Turkey. // Natural Hazards. 34, 1(2005), pp. 91-110. DOI: 10.1007/s11069-0041967-2

[6] Rafie, M.; Namin, F. S. Prediction of subsidence risk by FMEA using artificial neural network and fuzzy inference system. // Int. J. Min. Sci. Technol. 25, 4(2015), pp. 655663. DOI: 10.1016/j.jmst.2015.05.021

[7] Wu, Y.; Li, W.; Liu, P. et al. Application of Analytic Hierarchy Process Model for Landslide susceptibility Mapping in Ganghu County, Gansu Province, China. // Environ Earth Sci. 75, (2016), p. 422. DOI: 10.1007/s12665015-5194-9

[8] AFAD, Republic of Turkey, Prime Ministry Disaster and Emergency Management Authority, Preparation of Integrated hazard maps, Landslides-Rockfall, Basic Guide, Ankara (In Turkish), (2015). 
[9] Öztürk, K. Landslips and the effects of these on Turkey Gazi University. // Journal of Gazi Educational Faculty. 22, 2(2002), pp. 35-50 (In Turkish).

[10] Jiang, Q.; Chan, D.; Xiong, J. et al. Back Analysis of a Debris Landslide Based on Real Time Video Recording: Sliding Process and Post Slide Investigation. // Bull Eng Geol Environ. 75, 2(2016), pp. 647-658. DOI: 10.1007/s10064-015-0831-9

[11] Can, E. Investigation of landslide potential parameters on Zonguldak-Ereğli Highway and adverse effects of landslides in the region. // Environmental Monitoring and Assessment. 186, 4(2014), pp. 2435-2447. DOI: 10.1007/s10661-013-3550-3

[12] Tasoglu, I. K.; Keskin Citiroglu, H.; Mekik, C. GIS- Based Landslide Susceptibility Assessment: A Case Study in Kelemen Valley (Yenice-Karabuk, NW, Turkey. // Environ Earth Sci. 75, (2016), pp. 1291-1295. DOI: 10.1007/s12665-016-6098-z

[13] Atalay, I. F.; Bekaroglu, N. Landslides and Engineering Application, Republic of Turkey General Directorate For Highways. // Publication no: 200 Ankara, Turkey. (1973), 349p (In Turkish)

[14] Akın, B. ISO 9000 Applications, Business, Failure Mode and Effect Analysis (FMEA). Science and Technic Press, İstanbul. (1998), 182p (In Turkish)

[15] Chen J. K. Utility Priority Number Evaluation for FMEA. // Journal of Failure Analysis and Prevention. 7, 5(2007), pp. 321-328. DOI: 10.1007/s11668-007-9060-2

[16] Liu, H.-C.; Liu, L.; Liu, N. Risk Evaluation Approaches in Failure Mode and Effects Analysis: A Literature Review. // Expert Systems with Applications. 40, 2(2013), pp. 828838. DOI: 10.1016/j.eswa.2012.08.010

[17] Chin, K. S.; Wang, Y. M.; Poon, G. K. K.; Yang J. B. Failure mode and effects analysis using a group-based evidential reasoning approach. // Computers \& Operations Research. 36, (2009), pp. 1768-1779. DOI: 10.1016/..cor.2008.05.002

[18] Wang, Y.-M.; Chin, K.-S.; Poon, G. K. K.; Yang, J.-B. Risk Evaluation in Failure Mode and Effects Analysis Using Fuzzy Weighted Geometric Mean - Part 1. // Expert Systems with Applications. 36, 2(2009), pp. 1195-1207. DOI: 10.1016/j.eswa.2007.11.028

[19] Su, X.; Deng, Y.; Mahadevan, S.; Bao, Q. An Improved Method For Risk Evaluation in Failure Modes and Effects Analysis of Aircraft Engine Rotor Blades. // Engineering Failure Analysis. 26, (2012), pp. 164-174. DOI: 10.1016/j.engfailanal.2012.07.009

[20] Xiao, N.; Huang, H-Z.; Li, Y.; He, L.; Jin, T. Multiple Failure Modes Analysis And Weighted Risk Priority Number Evaluation in FMEA. // Engineering Failure Analysis. 18, 4(2011), pp. 1162-1170. DOI: 10.1016/j.engfailanal.2011.02.004

[21] Erbıyık H.; Can, E.; Kuşcu, S. Potential Risks And Their Analysis In The Application of Geographic Based Engineering Projects. // Technical Gazette. 21, 1(2014), pp. 9-15.

[22] Martinovic, K.; Gavin, K.; Reale, C. Development of a Landslide Susceptibility Assessment for a Rail Network. // Engineering Geology. 215, 19(2016) pp. 1-9. DOl: 10.1016/j.enggeo.2016.10.011

[23] URL 1 Pareto Diagram, http://tr.wikipedia.org/wiki/Pareto diyagram $\% \mathrm{C} 4 \% \mathrm{~B} 1$ (In Turkish) (2016)

\section{Authors' addresses}

\section{Eray Can}

Yalova University, Engineering Faculty, Department of Transportation Engineering, 77100, Yalova, Turkey can.eray@hotmail.com

\section{Hikmet Erbiyik}

Yalova University, Engineering Faculty, Department of Industry Engineering, 77100 , Yalova, Turkey hkerbiyik@gmail.com 